\title{
A Design and Implementation of ZigBee Educational System in USN Environment
}

\author{
Gyun Deuk Park ${ }^{\dagger} \cdot$ Joong Soo Chung $^{++} \cdot$ Kwang Wook Jung ${ }^{+++}$
}

\begin{abstract}
This paper has designed and realized educational ZigBee equipment befitting to the USN environment. In addition, this study has enabled users to exercise operation process for software technology education and to propose software design methods in the process in the USN environment through practice equipment for ZigBee education.

As for the development environment of system, Atmega128 process of Atmel is used for CPU; AVR compiler for the debugging environment; C language for firmware development language; and $\mathrm{C}^{++}$for application program. The system operation process is initiated by coordinator's sensing information reading order from the hyper terminal through a server through the Internet or directly connected; and then delivering it to a terminating device by using ZigBee technology. The terminating device delivers various sensing information to the coordinator which delivers it to a server through the Internet or to a HYPER terminal directly connected to the coordinator. As for the educational course, it is about practices on such ZigBee operation process and relevant programing skills. Regarding it, the communication between coordinator and terminating device is designed by utilizing physical layer of ZigBee protocol, MAC layer and network layer while the communication between server and coordinator is designed by proposing an independent protocol on TCP/IP socket and the protocol processing procedure during sensing data delivery is verified by interpretation.
\end{abstract}

Keywords : Embedded System, ZigBee, USN

\section{USN환경에서 교육용 ZigBee 장비의 설계 및 구현}

\author{
박 균 득 + 정 중 수 $^{++}$정 광 욱 $^{++}$
}

\begin{abstract}
요 약
본 논문에서는 USN 환경에 적합한 ZigBee 교육용 시스템을 설계 및 구현하였다. 또한 ZigBee 교육용 실습 장비를 통하여 사용자가 USN환 경에서 소프트웨어 기술 교육을 위하여 동작과정을 실습하고, 그 과정에서의 소프트웨어 설계 기법을 제시하였다.

시스템의 개발 환경으로 $\mathrm{CPU}$ 는 Atmel사의 Atmega128 프로세서, 디버깅 환경은 AVR 컴파일러, 펌웨어 개발 언어는 C언어를, 응용 프로그 램은 Visual $\mathrm{C}++$ 를 사용하였다. 시스템 동작 과정은 인터넷을 통한 서버나 직접 접속된 하이퍼 터미널로부터 코디네이터가 센싱정보 읽기 명 령을 수신한 후 이를 ZigBee 기술을 이용하여 종단장치로 전달함으로서 시작된다. 이후 종단 장치는 다양한 센싱정보를 코디네이터에게 전달하 며, 코디네이터는 인터넷을 통해 서버로 전달하거나 코디네이터에게 직접 접속된 하이퍼 터미널로 전달한다. 교육 과정으로는 이러한 ZigBee 동작과정에 대한 실습과 그에 대한 프로그래밍 기법이다. 이때 코디네이터와 종단장치간 통신은 ZigBee 프로토콜의 물리계층, MAC 계층, 네트 워크 계층을 활용하여 설계하였다. 또한 서버와 코디네이터간 통신은 TCP/IP 소켓위에 독자적인 프로토콜을 제시하여 설계하였고, 센싱된 데이 터를 전달시 프로토콜 처리과정을 해석하여 검증하였다.
\end{abstract}

키워드 : 임베디드 시스템, 지그비, USN

\section{1. 서 론}

※ 본 연구는 안동대학교 학술연구과제지원 사업으로 수행되었음.

† 정 회 원: 국립안동대학교 정보통신공학과

†† 정 회 원: 국립안동대학교 정보통신공학과 교수

†+† 정 회 원: 구미대학교 정보통신공학과 교수/(주)맨엔텔 대표이사 논문접수: 2012년 11월 28일

수 정 일 : 1 차 2013년 1 월 24 일

심사완료: 2013년 1월 25일

* Corresponding Author : Gyun Deuk Park(virus@andongmbc.co.kr)
최근 홈 네트워크와 유비쿼터스에 대한 관심이 높아지면 서 저속의 수십 미터 이내의 근거리 ZigBee 통신이 크게 주 목 받고 있다. 이 ZigBee 기술은 $\mathrm{u}$-센서네트워크(USN: Ubiquitous Sensor Network)의 구현에 중추적인 기술로 고 려된다. 통신 거리 관점에서 무선 개인영역 네트워크 (WPAN)은 단지 수 미터에만 이른다는 것을 의미하지만 실 
제 $\mathrm{ZigBee}$ 의 경우 통신거리가 수 백 미터까지도 가능하다 [1]. ZigBee는 IEEE 802.15.4표준의 물리 계층과 매체접근제 어 계층 위에 그 상위 계층으로 네트워크 계층, 응용지원 계층과 보안 및 응용 계층을 규격화한 것으로, 전송 대역폭 이 최대 $250 \mathrm{Kbps}$ 에 불과하나, 저가격 및 고 확장성으로 인 해 주로 산업 및 가정용의 무선 센서 네트워크 및 전자기기 제어에 주로 활용되고 있다[2]. 따라서 USN환경에 적합한 ZigBee와 ZigBee 프로토콜에 대한 이해를 위한 프로그래밍 실습이 요구되고 있다. 그러나 ZigBee 시스템을 이해하고 ZigBee 기술을 학습할 수 있는 교육용 장비는 부족하다. 기 존의 한백전자의 $\mathrm{HBE}-Z i g b e x \Pi[3]$, 휴인스의 UBEE430 series등[4]의 ZigBee장비의 경우 TinyOS를 사용함으로 운 영체제 내에 물리계층, $\mathrm{MAC}$ 계층, 네트워크 계층의 프로토 콜이 포함되어 패킷 분석이 불가능하며 실습생들은 간단한 구동 프로그램만을 실습해 볼 수 있어 ZigBee 기술을 이해 하기에 쉽지 않다.

본 논문에서는 $2.4 \mathrm{GHz}$ 대역의 $\mathrm{ZgBee}$ 프로토콜 흐름과 기술을 교육하는 ZigBee 소프트웨어 시스템을 개발하여 교 육용으로 활용 가능하도록 임베디드 하드웨어 상에 구현하 였다. 즉, $\mathrm{ZED}$ (ZigBee End Device)에서 센싱된 정보를 $\mathrm{ZC}$ (ZigBee Coordinator)까지 전달하는 과정의 프로토콜 흐 름과 그 응용 실습을 분석하도록 하였다.

$\mathrm{ZC}, \mathrm{ZED}$ 하드웨어의 구성은 $\mathrm{CPU}$ 로는 Atmel사의 Atmega128 16AU를 사용하고[5], 통신을 하기 위한 이더넷 부분과 모니터링을 위해 USB Interface를 채용하였다. 센싱 된 정보를 보내기 위해 Texas Instruments(TI)사의 CC2420 칩을 사용하였다[6]. 또한 $\mathrm{ZC}$ 에 접속되어 이를 제어하는 서 버의 소프트웨어 개발은 Visual C++를 사용하였다[7].

본 논문의 구성은 2장에서 ZigBee 교육용 시스템의 구조 에 대하여 설명하였다. 3장에서는 본 논문에 제안한 시스템 의 $\mathrm{ZC}$ 와 $\mathrm{ZED}$ 의 하드웨어 설계 개념, 이들을 통한 서버와의 프로토콜 흐름도, 서버의 소프트웨어 구조, 데모 프로그램의 설계 등의 구조를 설명하였다. 4장에서는 제안한 시스템을 실제 환경에서 적용한 기능 점검에 대하여 기술하였다. 마 지막으로 5 장에서는 본 연구의 결론과 향후 연구 방향에 대 하여 간략히 기술하였다.

\section{ZigBee 교육용 시스템의 실습 환경}

ZigBee 시스템에서 센싱 기능을 담당하는 ZED가 ZC를 경유하여 서버로 정보를 전송한다. 서버에서는 $\mathrm{ZED}$ 선택과 정과 ZED 센싱 정보를 번역하기 위해서 센싱 정보가 기록 된 $\mathrm{ZED}$ 데이터의 정보를 읽게 된다. 이를 위하여 $\mathrm{ZED}$ 는 온도센서, 습도센서, 압력 센서, 기울기 센서, 조도 센서, IR 센서 값에 해당하는 정보를 데이터 테이블에 기록되며, 서 버는 $\mathrm{ZC}$ 를 통해 $\mathrm{ZED}$ 에 기록된 정보를 가져와서 해석한다. ZED 센싱 데이터 읽기는 ZED의 정해진 메모리에서 수행하 는데, 실습생들은 기존의 데모 프로그램을 참고하여 이 데 이터를 목적에 맞게 수정할 수 있도록 하였다.

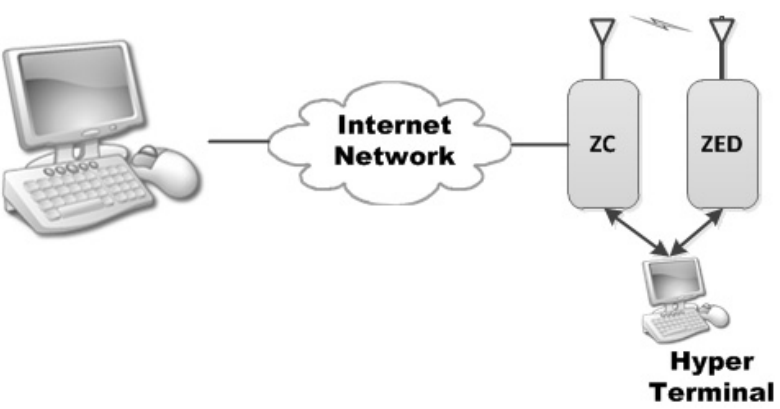

Fig. 1. ZigBee's Educational system

장비와 서버는 $\mathrm{USB}$ 를 통하여 장비 자체에서 모니터링 할 수 있도록 되어 있으며 이더넷을 통하여 외부 망과 접속 이 가능하도록 구성하였다[8].

\section{3. 시스템 설계 및 구현}

\section{1 설계 개념}

본 논문에서 구현한 시스템은 크게 하드웨어와 소프트웨 어 부분으로 나눌 수 있다. 하드웨어의 구조에서 시스템은 크게 $\mathrm{CPU}$ 부, 전원부, 모니터링부, $\mathrm{RF}$ 부로 구성된다. Fig. 2 에서 시스템의 $\mathrm{ZED}$ 를 나타내고, $\mathrm{ZC}$ 는 센서 대신 이더넷 접 속부가 포함된다.

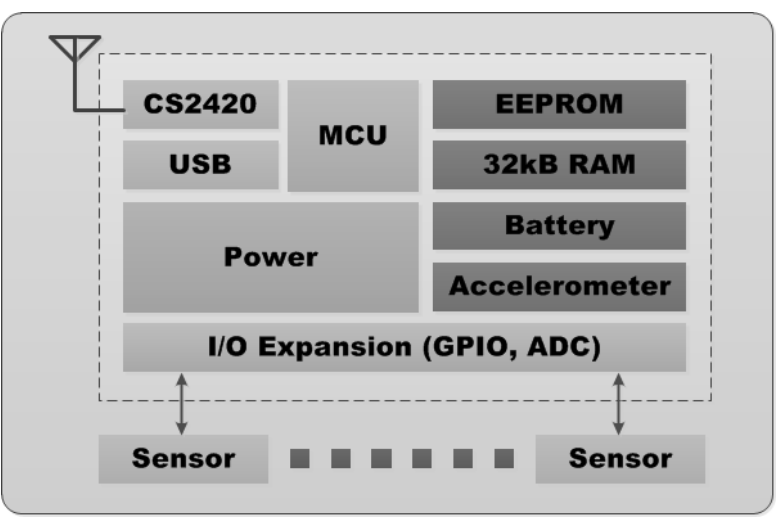

Fig. 2. ZED's Hardware configuration

통신부분은 서버와 인터넷 통신을 수행하기 위한 이더넷 부분과 모니터링 기능을 위한 USB 인터페이스 부분이 있다.

1) 이더넷 부 : $\mathrm{TCP} / \mathrm{IP}$ 기반으로 시스템과 $\mathrm{PC}$ 응용 프로그 램과의 인터넷 통신을 위하여 사용된다.

2) $\mathrm{RF}$ 부 : TI사의 $\mathrm{CC} 2420$ 칩을 사용하였으며 $2.4 \mathrm{GHz}$ 대역 의 주파수를 사용한다. Data Rate는 $250 \mathrm{kbps}$ 이며 QPSK 변조 방식을 사용한다.

3) 전원부 : USB VBus나 battery $4.5 \mathrm{~V}$ 를 정전압 칩을 사용 하여 $\mathrm{DC} 3.3 \mathrm{~V}$ 로 다운하여 사용한다.

4) $\mathrm{CPU}$ 부 : 8bits $\mathrm{RISC}$ 구조로 명령어가 간단하고 동작속 도가 빠르며, $16 \mathrm{MHz}$ 로 동작한다.

5) 리셋 : $\mathrm{RF}$ 칩과 이더넷 칩을 동시에 리셋 된다. 
6) $\mathrm{USB}$ 인터페이스 : 시스템을 $\mathrm{PC}$ 에서 모니터링을 위하여 시리얼 통신을 구현하였다[5].

\section{2 프로토콜 흐름도}

$\mathrm{ZED}, \mathrm{ZC}$ 의 펌웨어는 $\mathrm{Ad}-\mathrm{hoc}$ 네트워크로 전원을 켜고 네 트워크의 한 요소가 되면, 서로를 인식하기 위한 인식 과정 과 센싱 정보를 수집하는 기능을 수행한다.

$\mathrm{ZED}$ 에 접속된 센싱 정보를 읽기 위해서 $\mathrm{ZC}$ 와 이더넷 접 속 후 서버에서 $\mathrm{ZC}$ 로 Read 명령을 입력시키고, 입력된 정 보가 정상적으로 처리되는지 읽어보는 과정과 $\mathrm{ZC}$ 에 접속된 하이퍼터미널에서 물리계층, $\mathrm{MAC}$ 계층, 네트워크 계층까지 의 프로토콜 정보를 헥사값으로 화면에 디스플레이하여 기 능 점검을 수행한다.

1) 이더넷 접속 후 서버에서 $\mathrm{ZC}$ 로 Read 명령을 입력시킨다.

2) Read 명령을 수신한 $\mathrm{ZC}$ 는 $\mathrm{ZED}$ 로 $\mathrm{MAC}$ 계층의 Beacon 명령을 전달한다.

3) $\mathrm{ZED}$ 는 $\mathrm{MAC}$ 계층의 Association request 명령을 $\mathrm{ZC}$ 로 전송한다. 이후 $\mathrm{ZC}$ 가 이를 수신하여 $\mathrm{MAC}$ 계층의 Association response 명령을 ZED로 송신한다.

4) $\mathrm{ZED}$ 는 네트워크 계층의 route request 명령을 보내고 $\mathrm{ZC}$ 는 route response로 응답한다.

5) $\mathrm{ZC}$ 는 $\mathrm{ZED}$ 로 네트워크 계층의 데이터 패킷의 페이로드 필드에 센싱 정보 읽기인 Read 명령을 보낸다.

6) $\mathrm{ZED}$ 는 $\mathrm{ZC}$ 로 네트워크 계층의 데이터 패킷의 페이로드 필드에 센싱정보 결과인 Read 응답을 보낸다.

7) $\mathrm{ZED}$ 나 $\mathrm{ZC}$ 는 leave 패킷을 송신하여 네트워크 이탈과정 을 수행한다.

8) $\mathrm{ZED}$ 혹은 $\mathrm{ZC}$ 가 $\mathrm{MAC}$ 계층의 Disassociation notification 명령을 송신하여 네트워크 이탈과정을 수행한다.

\section{3 소프트웨어 설계}

데모과정을 파악하기 위해 ZigBee 시스템의 소프트웨어 는 $\mathrm{ZED}, \mathrm{ZC}$ 펌웨어와 인터넷에 접속된 서버 프로그램으로 구성된다.

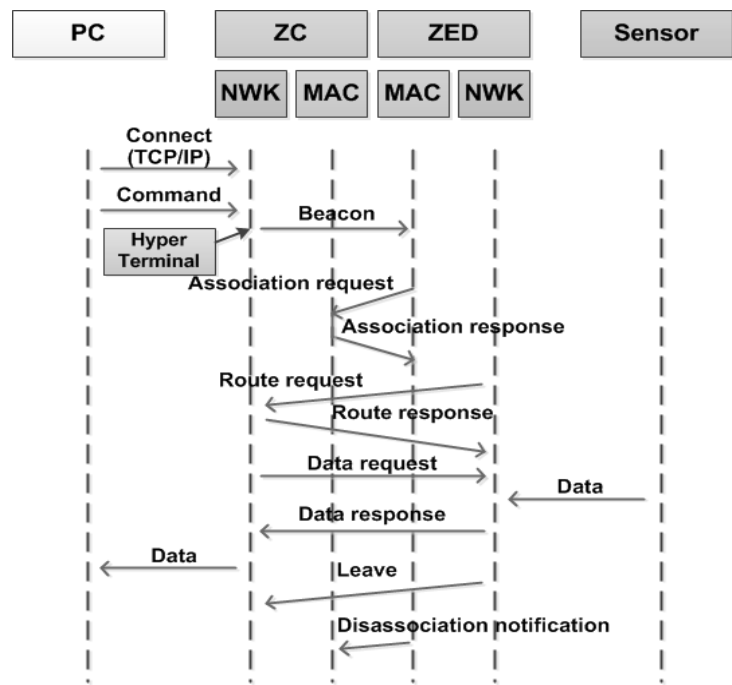

Fig. 3. Processing scenario of ZigBee System

본 논문에 소개되는 $\mathrm{ZC}$ 는 서버와 이더넷으로, $\mathrm{ZED}$ 와는 $2.4 \mathrm{GHz}$ 무선으로 접속되었다. 서버와 $\mathrm{ZC}$ 는 미들웨어 통신 규약을 준수하며 이는 독자적으로 통신 규약을 정의하여 처리하며, $\mathrm{ZC}$ 와 $\mathrm{ZED}$ 는 $\mathrm{IEEE} 802.15 .4$ 규격과 $\mathrm{ZigBee}$ Alliance규격을 준수한다. 소프트웨어 설계는 Fig. 4와 같이 $\mathrm{ZC}$ 로부터 $\mathrm{ZED}$ 데이터 정보의 송·수신 과정을 처리하는 미 들웨어와 $\mathrm{ZC}$ 와 $\mathrm{ZED}$ 간 통신과정을 설계하였다. 교육 과정으 로는 종단 장치가 다양한 센싱 정보를 ZigBee 기술을 이용 하여 코디네이터에게 전달시, IEEE802.15.4 규격과 ZigBee Alliance 규격의 네트워크 계층 처리과정의 프로토콜 흐름과 그에 따른 펌웨어 프로그램 구조를 분석한다. 또한 서버 없 이 하이퍼 터미널을 $\mathrm{ZC}$ 에 접속하여 $\mathrm{ZED}$ 의 센싱 정보를 읽 어오도록 하였다.

1) $\mathrm{PC}$ 와 $\mathrm{ZC}$ 의 미들웨어 통신 규약 적용 시 다음과 같이 통 신 조건을 가정한다.

(1) $\mathrm{ZED}$ 의 각종 센싱 정보를 읽어오는 $\operatorname{Read}$ 명령으로 처 리한다.

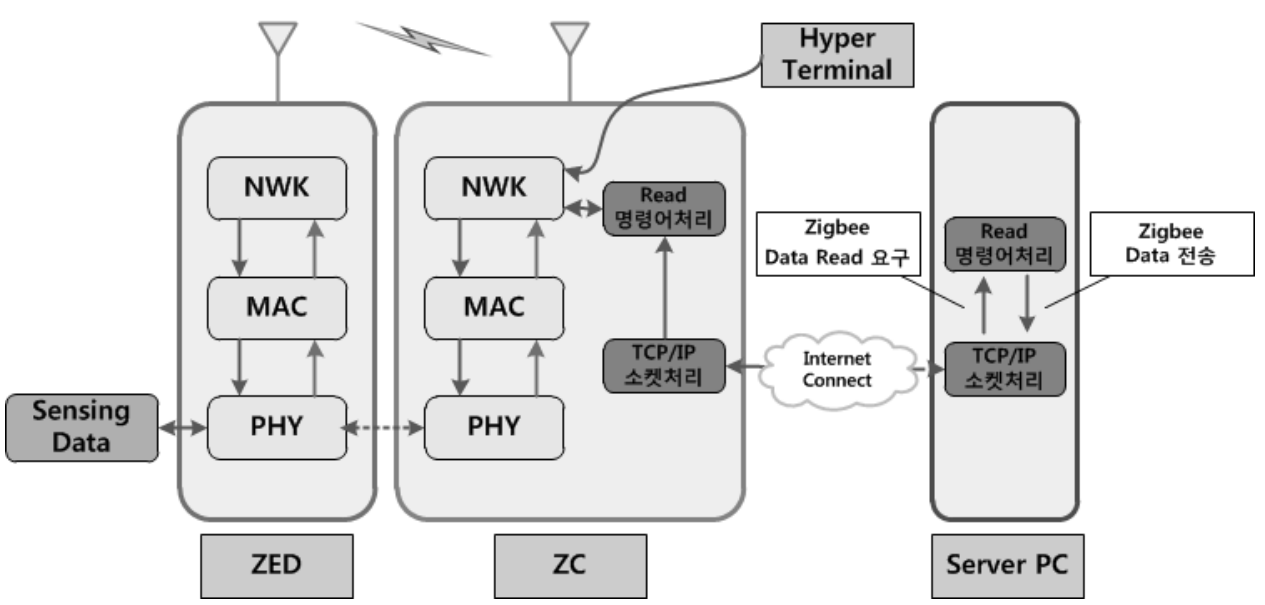

Fig. 4. The structure of the designed software 
(2) ZC는 TCP Sever, 서버는 TCP Client 로 동작한다.

(3) $\mathrm{ZC}$ 는 6 개 종류의 센서가 부착된 $\mathrm{ZED}$ 를 초기화시 펌웨 어에 $\mathrm{ID}$ 를 1 번에서 6 번까지 설정하여 관리한다.

(4) $\mathrm{ZC}$ 는 서버가 설정된 $\mathrm{ID}$ 가 오면, 그것을 $\mathrm{ZED}$ 측으로 전 달한다.

(5) 서버는 $\mathrm{TCP} 4000, \mathrm{ZC}$ 는 $\mathrm{TCP} 3000$ 으로 접속한다.

(6) 소켓 접속 후에 명령어를 전달한다.

2) 서버와 $\mathrm{ZC}$ 의 미들웨어 통신 규약 적용 시 명령 / 응답 구조는 다음과 같이 정의 한다.

(1) 첫 번째 바이트는 $\mathrm{ZED}$ 에 정보를 읽기를 나타내며, 0x01이 $\operatorname{Read}$ 기능을 의미한다.

(2) 두 번째 바이트는 ZED번호이다.

(3) $\mathrm{ZED}$ 의 센싱 정보를 읽는 Read 명령 기능의 패킷 구조 는 다음과 같다.

· 명령 구조: 0x01 0x01-0x06 0x01

· 응답 구조: 0x01 0x01-0x06 0x01 4바이트 데이터 로 2byte 센서 형태이고 나머지 2byte는 센싱 값 이다.

(4) 첫 번째, 네 번째 바이트는 사용하지 않는다.

\subsection{1 서버의 소프트웨어 구조}

본 논문에 소개되는 서버는 $\mathrm{ZC}$ 를 제어하기 위해 $\mathrm{ZC}$ 와 인터넷으로 접속된다. 서버 $\mathrm{PC}$ 의 소프트웨어는 Visual $\mathrm{C}++$ 를 사용하여 다이얼로그 베이스로 설계하였다. 이는 $\mathrm{ZED}$ 센싱 데이터의 읽기 기능을 처리하는 데모 프로그램으로 실 습생들이 실습가능 하도록 하였다.

\subsubsection{ZC의 소프트웨어 구조}

미들웨어 기능을 수행하는 서버로부터 수신된 $\operatorname{Read}$ 기능 처리를 전달받아 IEEE802.15.4 규격과 ZigBee Alliance규격 의 형태로 변환하여 $\mathrm{ZED}$ 로 전달하며, 그에 대해 $\mathrm{ZED}$ 로부 터 수신되는 응답 중 센싱 종류와 센싱값을 $\mathrm{PC}$ 로 전달하 는 기능을 수행하며 그 구성도는 Fig. 5와 같다.

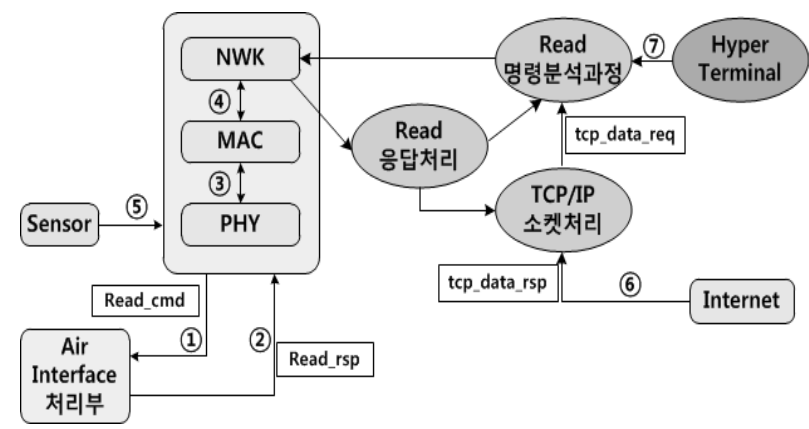

Fig. 5. ZC's Software structure

$\mathrm{ZED}$ 의 동작과정을 살펴보면 다음과 같다. (1), (2), (3), (4), (5), (6), (7)은 각 기능 간 시그널 전달을 의미한다.

(1), (2)는 $\mathrm{ZED}$ 와 패킷 송-수신 시 호출되는 프리미티브로 (1)은 $\mathrm{ZED}$ 로부터 명령패킷 수신 처리부로 명령패킷이 전달
될 때 호출되며 그 형식은 $\mathrm{tx}(\mathrm{uchar} * \mathrm{ptr}$, uint len)이다. *ptr는 정보를 전달하는 데이터의 시작주소이고, len은 그 정보의 길이이다. (2)는 $\operatorname{rx}(u$ char *ptr, uint len)이며, 응답패 킷송신처리에서 펌웨어로 응답패킷이 전달될 때 호출된다. (3)은 (1)에서 명령 패킷 수신 시 IEEE 802.15.4의 MAC 계 층처리를 하고 (4)에서는 네트워크 계층 처리 후 (5)의 센싱 정보를 읽어서 ZigBee 프로토콜 헤더를 없애고, TCP/IP 헤 더를 추가하여 $\operatorname{Read}$ 응답처리 후 $\mathrm{TCP} / \mathrm{IP}$ 소켓 구동하여 인 터넷으로 서버에게 전달한다.

(6)은 $\mathrm{TCP} / \mathrm{IP}$ 소켓 접속 후 인터넷에서 접속된 서버와 송. 수신되는 명령/응답처리 기능인데, 이러한 서버로부터 전달받은 명령 수신 정보를 전달하는 프리미티브는 tcp_data_req(uc *ptr, int len)이며, ZED로부터 수신되는 응 답 중 Read 기능 처리 후 서버로 센싱 형태와 센싱 값을 전달하는 프리미티브는 tcp_data_rsp(uc * ptr, int len)로 설 정하였다.

(7)은 서버 없이 하이퍼 터미널을 $\mathrm{ZC}$ 에 접속하여 $\mathrm{ZED}$ 의 센싱 정보를 읽는 기능을 한다.

\subsection{3 능동형 $\mathrm{ZED}$ 의 소프트웨어 구조}

$\mathrm{ZED}$ 는 $\mathrm{ZC}$ 로 부터 Read 명령 처리를 IEEE802.15.4 규격 과 ZigBee Alliance규격의 형태로 수신하여 센싱 값을 전달 한다.

$\mathrm{ZED}$ 의 동작과정은 $\mathrm{ZC}$ 의 소프트웨어 구조와 유사하며, 인터넷 처리부분은 제거되고 센서처리 소프트웨어가 추가 된다.

\section{4. 시스템 기능점검 및 성능분석}

개발된 시스템의 기능 점검은 Fig. 6과 같이 서버와 $\mathrm{ZC}$, $\mathrm{ZC}$ 와 $\mathrm{ZED}$, 그리고 서버, $\mathrm{ZC}, \mathrm{ZED}$ 의 연동에 대하여 검증하 였다. 마찬가지로 서버와 $\mathrm{ZC}$ 의 이더넷 접속에 대해서도 점 검하였다. $\mathrm{ZC}$ 는 $\mathrm{TCP}$ Server로, 서버는 $\mathrm{TCP}$ Client로 동작 하는지를 점검하였고, $\mathrm{ZC}$ 는 서버로부터 $\mathrm{ZED}$ 에 접속된 센서 데이터의 읽기 기능 처리를 위한 서버와 정보 전달 및 IEEE802.15.4 규격과 ZigBee Alliance규격의 형태로 처리가 정상적으로 되는지를 점검하였다.

점검과정은 $\mathrm{ZED}$ 와 $\mathrm{ZC}$ 를 거친 서버에서의 점검과 $\mathrm{ZED}$ 와 $\mathrm{ZC}$ 간 $\mathrm{ZigBee}$ 통신과정의 점검이 있다.

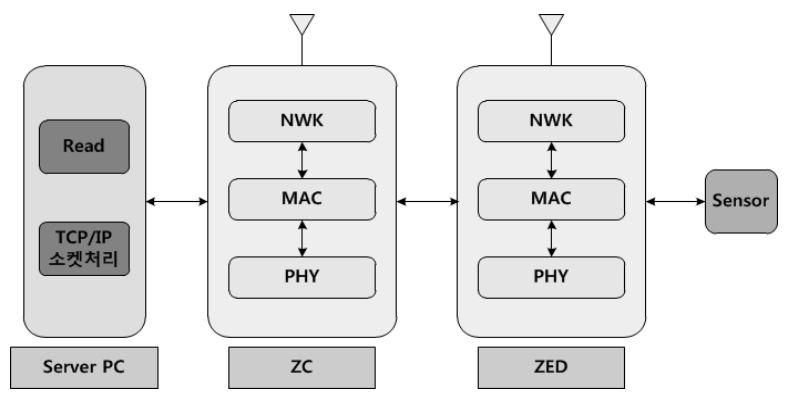

Fig. 6. Checking structure in server 
4.1 서버에서의 점검

소프트웨어의 처리화면구조는 Fig. 7과 같은 화면에 출력 된다.

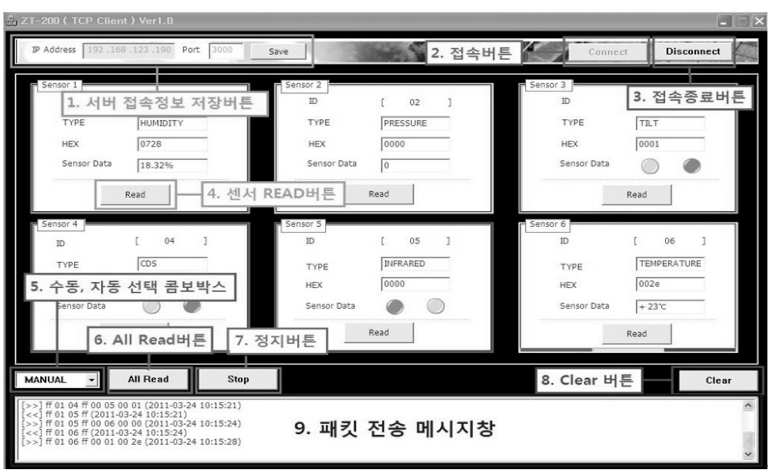

Fig. 7. Software processing

\subsection{ZED와 ZC간 ZigBee 통신과정의 점검}

하이퍼터미널을 $\mathrm{ZC}$ 에 접속하여 물리계층, $\mathrm{MAC}$, 네트워 크 계층의 단계별 처리가 있다. 아래는 그 대표적으로 네트 워크 계층의 점검과정을 분석하였다.

send read net [Address]: 데이터 링크, 네트워크 계층 처 리 후 $\mathrm{ZED}$ 의 센싱 정보 읽어오기이다

[Address]: 십진수 값 입력

Fig. 8은 ZED에서 센싱 정보 읽기 수행 중 Beacon 프레 임 전달과정만 살펴본 과정이다.

이후 Fig. 9는 네트워크 계층의 데이터 프레임의 센싱 종 류와 정보 읽기 결과를 나타낸다.

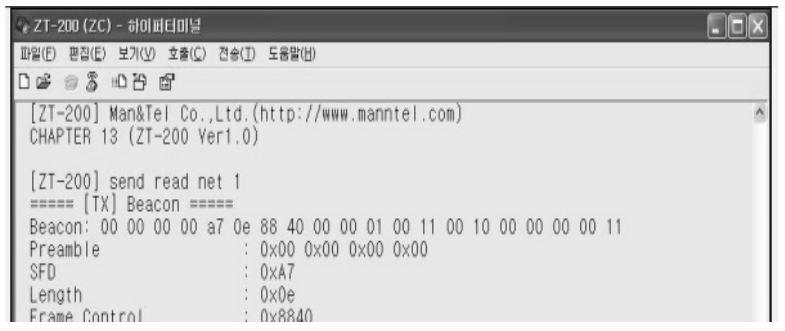

Fig. 8. Beacon frame forwarding process

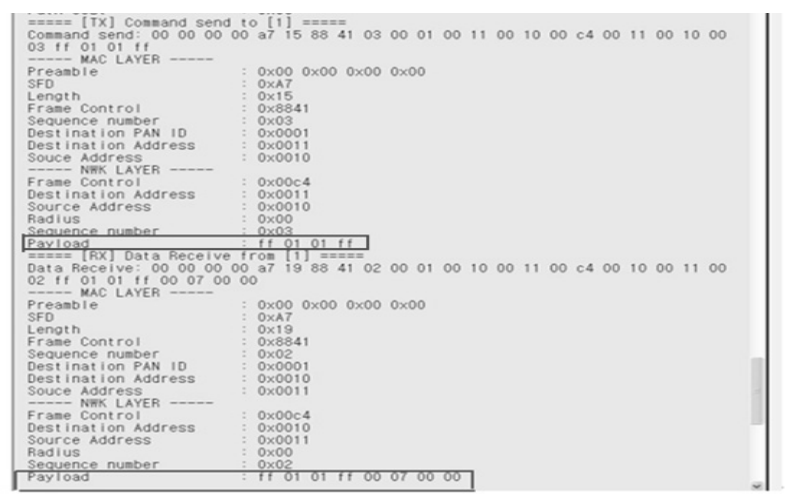

Fig. 9. The result of information reading

\section{3 성능분석}

$\mathrm{ZED}$ 와 $\mathrm{ZC}$ 로 구성된 교육용 $\mathrm{ZigBee}$ 시스템의 개발 이후 성능파악이 매우 중요하다. 하이퍼 터미널과 $\mathrm{ZED}, \mathrm{ZC}$ 간 패 킷 송·수신시 프리미티브 함수는 4 번 호출되며 하나의 프리 미티브를 처리하는 시간은 약 $5 \mathrm{~ms}$ 이다. 또한 센서로부터 $\mathrm{ZED}, \mathrm{ZC}$ 로 패킷이 전달되어 $\mathrm{MAC}$ 계층, 네트워크 계층 처리 함수는 $\mathrm{ZED}$ 에서 2 번, $\mathrm{ZC}$ 에서 2 번 호출되며, $\mathrm{MAC}$ 과 네트워 크 계층을 처리하는데 걸리는 시간은 약 $16 \mathrm{~ms}$ 가 된다. 센서 에서 센싱된 정보를 읽는 시간은 평균 $3 \mathrm{~ms}$ 이므로, 하나의 센싱 정보를 처리하는 데 걸리는 시간은 다음과 같다.

\section{센싱 정보를 읽는 시간 : $3 \mathrm{~ms}$}

$\mathrm{MAC}$, 네트워크 계층 처리 시간 : $16 \mathrm{~ms} * 4=64 \mathrm{~ms}$

송·수신 프리미티브 처리 시간 : $5 \mathrm{~ms} * 4=20 \mathrm{~ms}$

따라서 하이퍼 터미널을 $\mathrm{ZC}$ 에 접속하여 센싱 형태와 센 싱 값을 전달하는 시간을 모두 포함하면 시스템의 처리 속 도는 약 $90 \mathrm{~ms}$ 가 된다. 따라서 교육용 ZigBee 시스템에서 하 나의 센싱 데이터를 처리하는 데 $90 \mathrm{~ms}$ 가 소요되므로 초당 약 11 개의 센싱 정보를 처리할 수 있다. 이러한 결과는 ZigBee 시스템의 교육용으로서의 성능은 충분히 만족한다.

\section{5. 결론 및 향후 연구}

본 논문에서는 $2.4 \mathrm{GHz}$ 대역의 ZigBee 프로토콜 흐름과 기술을 교육하는 ZigBee 소프트웨어를 설계하였다. 설계된 시스템은 $\mathrm{ZC}, \mathrm{ZED}$ 노드로 구성되어 교육용으로 활용 가능하 도록 임베디드 하드웨어 상에 구현하였다.

ZigBee통신을 기반으로 한 교육용 장비를 개발하여 프로 토콜을 계층별로 분석할 수 있는 프로그램을 설계하고 그 기법을 제시하였다.

$\mathrm{ZC}, \mathrm{ZED}$ 하드웨어의 구성은 $\mathrm{CPU}$ 로는 Atmel사의 Atmega128 16AU를 사용하고, 센싱된 정보를 보내기 위해 TI사의 CC2420 칩을 사용하였다. Visual C++ 언어를 사용 하여 $\mathrm{ZC}$ 를 제어하는 호스트 및 서버 소프트웨어를 설계하 였다.

또한 이의 검증으로 $\mathrm{ZC}$ 를 하이퍼터미널에 접속하거나 인 터넷을 통한 서버에서의 접속을 통하여 물리계층, $\mathrm{MAC}$ 계 층, 네트워크 계층의 계층별로 단계적으로 처리하고 그 과 정을 분석하였다.

지금까지는 물리계층, $\mathrm{MAC}$ 계층, 네트워크 계층까지만 교육용으로 설계되었으나, 향후 상용화된 ZigBee 보드와 접 속이 가능하도록 설계되어야 할 것이다.

\section{참 고 문 헌}

[1] http://www.ZigBee.org

[2] IEEE 802.15.4-2003 IEEE Standard for Information 
Technology-Part 15.4: Wireless Medium Access Control (MAC) and Physical Layer(PHY) specification for Low Rate Wireless Personal Area Networks (LR-WPANs), 2003.

[3] http://www.hanback.co.kr/products/view/21

[4] http://www.huins.com/m16.php?m=rd\&no=76

[5] http://www.atmel.com/devices/atmega128.aspx

[6] http://www.ti.com/product/cc2420

[7] Jae-chang Sim, "the application of ZigBee technology and practice", Hongrueng Science Publishers, 2007.

[8] Joong-soo Chung, Kwang Wook Jung, "ZigBee communication Experiments(by using ZT-200)"

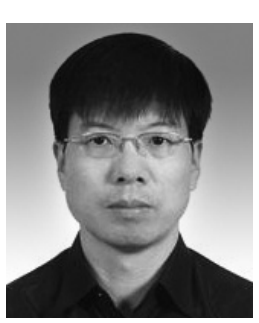

\section{박 균 득}

e-mail : virus@andongmbc.co.kr 1997년 광운대학교 전자재료공학과(학사) 2003년 경북대학교 전자공학과(석사) 2004년 정보통신기술사 취득

2012년 안동대학교 정보통신공학과

$$
\text { (박사수료) }
$$

1997년 현 재 안동문화방송 기술팀 근무 관심분야: 인터넷 통신, 정보통신, 이동통신

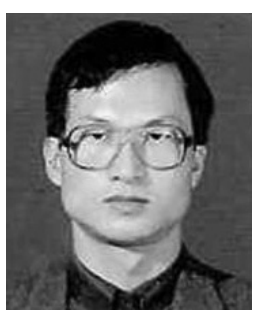

정 중 수

e-mail :jschung@andong.ac.kr

1981년 영남대학교 전자공학과(학사)

1983년 연세대학교 전자공학과(석사)

1993년 연세대학교 전자공학과(박사)

1983년 1994년 ETRI 연구원, 선임연구원

1987년 1989년 벨지움 Alcal/Bell

Telephone사 객원연구원

2000년 2001년 미국 UMASS/Lowell 전산학과 객원교수 1994년 현 재 국립안동대학교 공과대학 정보통신공학과 교수 관심분야: 컴퓨터 네트워크, 인터넷 통신, 무선통신

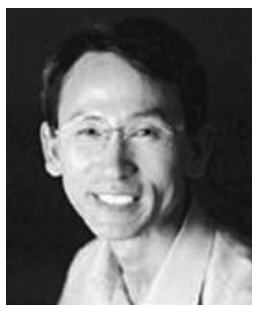

\section{정 광 욱}

e-mail : kwjung@kumi.ac.kr 1982년 경북대학교 전자공학과(학사) 1984년 경북대학교 전자공학과(석사) 1984년 1992년 삼성전자 책임연구원 1996년 경북대학교 전자공학과(박사) 1992년 현 재 구미대학교 정보통신공학과 교수

2000년 현 재 (주)맨엔텔 대표 2011년 현 재 (주)맨엔헬스 대표 관심분야: 무선통신, IT-의료융합기기 